\title{
Activity of lysosomal exoglycosidases in submandibular glands of rats intoxicated by cadmium at doses related to human chronic environmental and occupational exposures ${ }^{\star}$
}

\author{
Anna Zalewska ${ }^{1}$, Małgorzata M. Brzóska ${ }^{2}$, Justyna Marciniak ${ }^{1}$, Katarzyna \\ Karaszewska $^{1}$, Krzysztof Zwierz ${ }^{1 \varpi}$ and Janina Moniuszko-Jakoniuk ${ }^{2}$ \\ ${ }^{1}$ Department of Pharmaceutical Biochemistry, ${ }^{2}$ Department of Toxicology, Medical University \\ of Biatystok, Biatystok, Poland
}

Received: 06 March, 2003; revised: 12 January, 2004; accepted: 25 February, 2004

Key words: exoglycosidases, $\beta$ - $N$-acetylhexosaminidase, $\alpha$-mannosidase, $\beta$-galactosidase, salivary glands of rats, cadmium

\begin{abstract}
Work in cadmium (Cd) smelter and smoking cigarettes damages teeth and oral mucosa which are protected by tissue and salivary glycoconjugates: glycoproteins, glycolipids, and proteoglycans. We worked out a rat model imitating human "environmental" and "occupational" exposure to cadmium using $5 \mathrm{mg} \mathrm{Cd}$ and $50 \mathrm{mg} \mathrm{Cd} / \mathrm{l}$ in drinking water, respectively. In submandibulary glands of exposed to $\mathrm{Cd}$ rats, we found the time and dose dependent accumulation of $\mathrm{Cd}$ and simultanous decrease in activity of $\beta$ - $N$-acetylhexosaminidase (HEX).

In homogenates of submandibulary glands of control rats, $\beta-N$-acetylhexosaminidase showed the highest activity. The activities of $\alpha$-mannosidase and $\beta$-galactosidase were very low. None of these exoglycosidases were inhibited by $\mathrm{Cd}$ even at 44 $\mathrm{mM}$ concentration.
\end{abstract}

Cadmium (Cd) is recognized as one of the most toxic metals with very strong accumulation, and a half-life of 26 years in human body (WHO, 1992; Indulski, 1996). Humans are exposed to cadmium from the environment (including smoking) and industry. By smoking 20 cigarettes one may absorb $1-2 \mu \mathrm{g}$ of $\mathrm{Cd}$ into the blood (WHO, 1992; Indulski, 1996). The toxicity of cadmium towards kidneys, bones, respiratory tract and haemopoiesis (WHO, 1992; Mitsumori et al., 1998) has been well documented. Influence of cadmium on salivary glands has not been studied so far. As it was impossible to examine human sali-

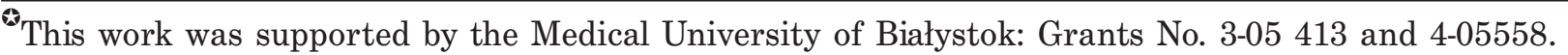

${ }^{\square}$ Corresponding author: Krzysztof Zwierz, Department of Pharmaceutical Biochemistry, Medical University, Adama Mickiewicza 2a; 15- 222 Białystok 8, Poland; tel: (48 85) 748 5691; fax: (48 85) 748 5416; e-mail: kzwie@amb.edu.pl

Abbreviations: Gal, $\beta$-galactosidase; HEX, $\beta$ - $N$-acetylhexosaminidase; Man, $\alpha$-mannosidase.
} 
vary glands, we worked out an animal model (Brzóska et al., 2003). Using this model we evaluated concentrations of cadmium and changes in the activity of glycosidases in rat salivary glands after chronic exposure to 5 $\mathrm{mg} / \mathrm{l} \mathrm{Cd}$ of drinking water (imitating human environmental exposure) and $50 \mathrm{mg} / \mathrm{l}$ of drinking water (imitating human occupational exposure).

There are four reasons for choosing submandibulary glands as the target to investigate the action of cadmium on exoglycosidases. First, the rat submandibulary gland produces and contains glycoconjugates: glycoproteins (Wu et al., 1994) and proteoglycans (Kinoshita et al., 1986), and possess enzymes taking part in degradation of their sugar chains: $\beta$-glucuronidase (Sugiyama, 1975), hyaluronidase (Kano, 1986), $\beta$ - $N$-acetylhexosaminidase (Shioji et al., 1988) and $\beta$-galactosidase (Kamada et al., 1989). Second, the submandibulary gland has the highest activity of $\beta$ - $N$-acetylhexosaminidase among the salivary glands of rat, as sublingual gland has only $17 \%$ and the parotid gland $8 \%$ of its activity (Shioji et al., 1988). Third, these glands produce salivary glycoproteins which protect tooth enamel against demineralization (Nieuw-Amerongen et al., 1987) and caries (Lagrelof \& Olivery, 1994). Salivary glycoproteins lubricate and moisturize oral mucosa (MG1, MG2, PRG), maintain constant $\mathrm{pH}$ of saliva (peroxidase, carbonic anhydrase), and are involved in digestion of food (MG1, MG2, amylase) (Douglas \& Golub, 1994). They also regulate periodontal wound healing (Zenther \& Heaney, 1995), agglutinate bacteria (MG1, MG2, PRG, SAG, sIgA), regulate bacterial colonization in the oral cavity (MG1, MG2, PRG, SAG, fibronectin), and act antibacterially (lactoferrin, amylase, peroxidase, sIgA). The fourth reason is that workers employed in $\mathrm{Cd}$ smelters suffer from serious periodontopathies (Stawinski et al., 1987). Also negative effects of smoking on teeth and whole oral cavity, have been well documented (Martinez-Canut et al., 1995)

\section{MATERIALS AND METHODS}

Animals. In vivo studies were carried out on 48 male Wistar rats, 2-month-old, at an initial body mass of $180-200 \mathrm{~g}$. All the animals were kept in standard conditions, had unlimited access to standard diet (LSM dry diet, Motycz, Poland) and drinking water (redistilled water with or without $\mathrm{CdCl}_{2}$ ). The rats were allocated randomly to three experimental groups of 16 animals each. Two groups received, as the only drink, water solution of $\mathrm{CdCl}_{2}$ at $5 \mathrm{mg} / \mathrm{l}$ (equivalent to "environmental" exposure) or $50 \mathrm{mg} / \mathrm{l}$ (equivalent to "occupational" exposure). The control group drank redistilled water (without $\mathrm{Cd}$ ).

Tissue preparation. All the animals used for experiments were fasted for $24 \mathrm{~h}$, then glandectomized under anaesthesia with enfluran and sacrificed. The glands were washed with $0.9 \% \mathrm{NaCl}$, trimmed of fat, weighed and homogenized at $4^{\circ} \mathrm{C}$ in a Polytron type homogenizer in 10 volumes of $0.15 \mathrm{M} \mathrm{KCl}$ containig $0.2 \%$ Triton X-100. The resulting homogenate was centrifuged at $12000 \times \boldsymbol{g}$ for $30 \mathrm{~min}$ at $4^{\circ} \mathrm{C}$. The supernatant was used as crude enzyme solution.

The Local Ethics Committee for animal experiments in Bialystok approved the study. Procedures involving animals and their care conformed to institutional guidelines, in compliance with national and international laws and Guidelines for the Use of Animals in Biomedical Research (Giles, 1987).

Chemicals. The substrates and standard solution of $\mathrm{Cd}$ were commercial preparations from Sigma Chemical Co. (St. Louis, Mo, U.S.A.). $\mathrm{HNO}_{3}$ was purchased from Merck. All the reagents were dissolved in redistilled water (Millipore System Milli RO- Milli Q).

Cadmium concentration. The submandibular glands of rats were dried and mineral- 
ized in an electrical muffle furnance. Cd concentration was determined by flameless atomic absorption spectrometry (Zeeman Atomic Absorption Spectrophotometer Z-5000, Hitachi) with electrothermal atomization in a graphite cuvette. The cathode lamp for $\mathrm{Cd}$ was operated under standard conditions using its resonance line of $228.8 \mathrm{~nm}$. The Cd concentration was expressed in $\mu \mathrm{g} / \mathrm{g}$ of wet tissue.

Exoglycosidases. Before the activity was determined, the crude supernatants were diluted with $0.15 \mathrm{M} \mathrm{KCl}$ containing Triton X-100 as follows: 100 fold for $\beta$-N-acetylhexosaminidase (HEX), 10 fold for $\beta$-galactosidase (Gal) and 20 fold for $\alpha$-mannosidase (Man). Determination of enzyme activity was performed according to Zwierz et al. (1981), as follows: to $0.05 \mathrm{ml}$ of the diluted supernatant, $0.1 \mathrm{ml}$ of $0.1 \mathrm{M}$ phosphate/citrate buffer, $\mathrm{pH}$ 4.7, for $\beta$-N-acetylhexosaminidase, and $\mathrm{pH} 4.3$ for the other enzymes, was added. Then 0.05 $\mathrm{ml}$ of $20 \mathrm{mM}$ solution of an appropriate substrate ( $\alpha$ - or $\beta$-p-nitrophenyl glycoside) was added and the tubes incubated, at $37^{\circ} \mathrm{C}$ for 60 min. The reaction was terminated in an ice-bath by adding $1.0 \mathrm{ml}$ of $0.2 \mathrm{M}$ potassium tetraborate buffer, $\mathrm{pH}$ 9.8. The samples were mixed and centrifuged at $14000 \times \boldsymbol{g}$ for 6 min. The absorbance of liberated p-nitrophenol was measured at $410 \mathrm{~nm}$ in duplicate and appropriate standard solutions were analysed in parallel. Specific activities were expressed in kat/g of protein (katal $=$ the amount of activity that converts one mole of substrate per second) according to the IUPAC-IUB Recommendations 1972 (Florkin \& Stotz, 1973).

Direct influence of $\mathrm{CdCl}_{2}$ on the activity of glycosidases in crude supernatants from homogenates of submandibulary glands of 2-month old rats, not exposed to cadmium, was also investigated. The reaction mixture consisted of $0.05 \mathrm{ml}$ of $100 \times$ diluted supernatant, $0.175 \mathrm{ml}$ of phosphate/citrate buffer, $\mathrm{pH} 4.7$, and $0.025 \mathrm{ml}$ of $\mathrm{CdCl}_{2}$ at a concentration from 5 to $50 \mathrm{mg} \mathrm{Cd}^{+2} / \mathrm{ml}$. Samples were preincubated at $37^{\circ} \mathrm{C}$ for $20 \mathrm{~min}$, then to each sample $0.15 \mathrm{ml}$ of $20 \mathrm{mM}$ solution of substrate was added and samples were incubated at $37^{\circ} \mathrm{C}$ for $60 \mathrm{~min}$. Reaction was stopped by adding $1 \mathrm{ml}$ of $0.2 \mathrm{M}$ borate buffer, $\mathrm{pH} 9.8$. After alkalization, the samples were centrifuged $(20 \mathrm{~min}$ at $14000 \times \mathrm{g})$, and the liberated p-nitrophenol was measured at $410 \mathrm{~nm}$.

The protein content was determined by the biuret method with bovine serum albumin as a standard (Gornal et al., 1949).

Statistical analysis. Statistical analysis was conducted with software package Statistica (Statsoft). As our variables had normal distribution we performed Levine's test to determine the homogeneity and analysis of variances. This revealed significant differences between groups. We used post hoc analysis calculated by the NIR test. Results were expressed as the mean \pm S.D. $P$ values of less than 0.05 were considered significant.

\section{RESULTS}

Cadmium concentrations in submandibular glands of rats exposed for 6 or 24 weeks to "environmental" or "occupational" doses of cadmium are presented in Fig. 1. In submandibular glands of rats exposed to "occupational” doses of Cd for 24 weeks, the Cd concentration was significantly increased, in comparison to the rats exposed to "environmental" doses for the same period, as well as to those exposed for 6 weeks to the same $\mathrm{Cd}$ doses. However, "occupational" exposure for 24 weeks caused significant twofold increase in concentration of $\mathrm{Cd}$ in the submandibulary gland, in comparison to 6 weeks exposure (Fig. 1).

Figure 2 presents the high activity of HEX in the rat submandibular glands homogenate. Activities of Man and Gal were 12 and 36 times lower than HEX, respectively. $\mathrm{Cd}$ at concentrations from 4.4-44 mM had no effect neither on activities of HEX, nor Man or Gal (Fig. 2). 


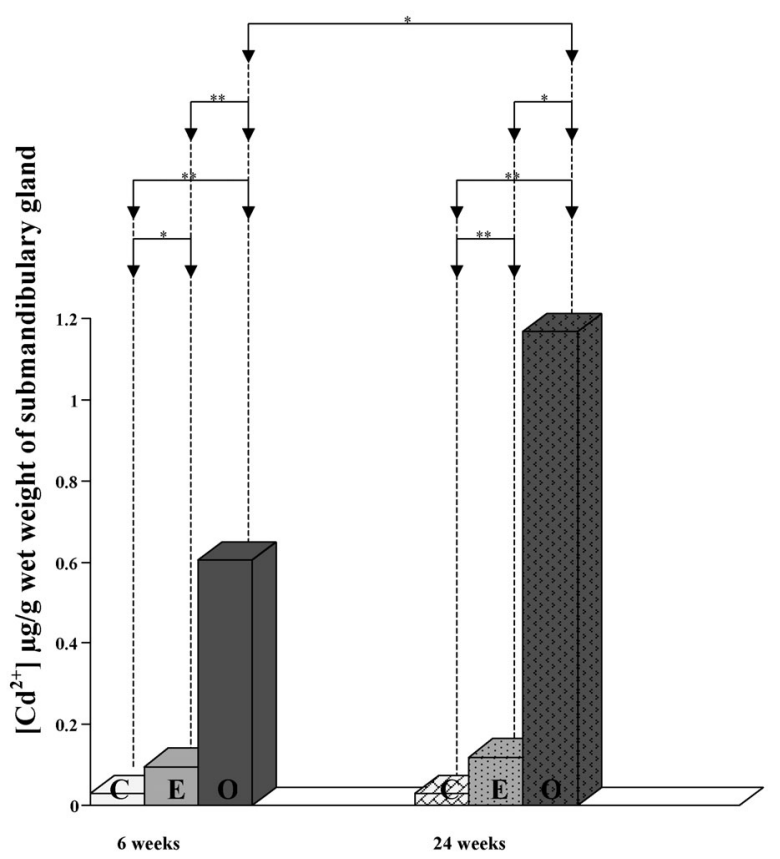

Figure 1. Accumulation of cadmium in submandibulary glands of rats chronically exposed to cadmium.

Concentration of $\mathrm{Cd}^{2+}$ in submandibulary glands of control rats (C); after „environmental“ exposure -5 $\mathrm{mg} \mathrm{Cd} / \mathrm{l}$ drinking water (E); after „occupational” exposure $-50 \mathrm{mg} \mathrm{Cd} / 1$ drinking water $(\mathrm{O}) . P \leq 0.05$; $P \leq 0.001$.

HEX activities in submandibular glands of rats exposed to the "environmental" dose of Cd for six weeks and to the "ocupational" dose for 24 weeks are presented in Fig. 3. Very evident decrease in HEX activity was observed, both when rats were exposed to „occupational” dose for 24 or 6 weeks. However, there was no change in HEX activity after exposure to the "environmental" dose for 6 weeks.

\section{DISCUSSION}

Toxic effects of cadmium on kidneys (Brzóska et al., 2003), bones, and the respiratory tract are well documented (Mitsumori et al., 1998), but the influence of cadmium on the salivary gland was not studied so far. We elaborated a rat model related to conditions in human (Brzóska et al., 2003). Using this model we measured cadmium concentration

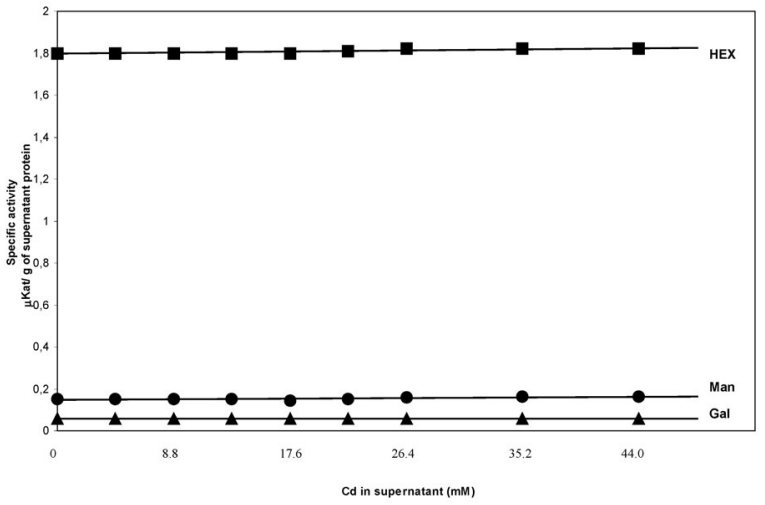

Figure 2. The supernatant from submandibulary glands was preincubated with $\mathrm{Cd}$ for $20 \mathrm{~min}$ at $37^{\circ} \mathrm{C}$, than the reaction was started by addition of substrates.

Further procedure as described in Materials and Methods. Other details see in description to Fig. 1.

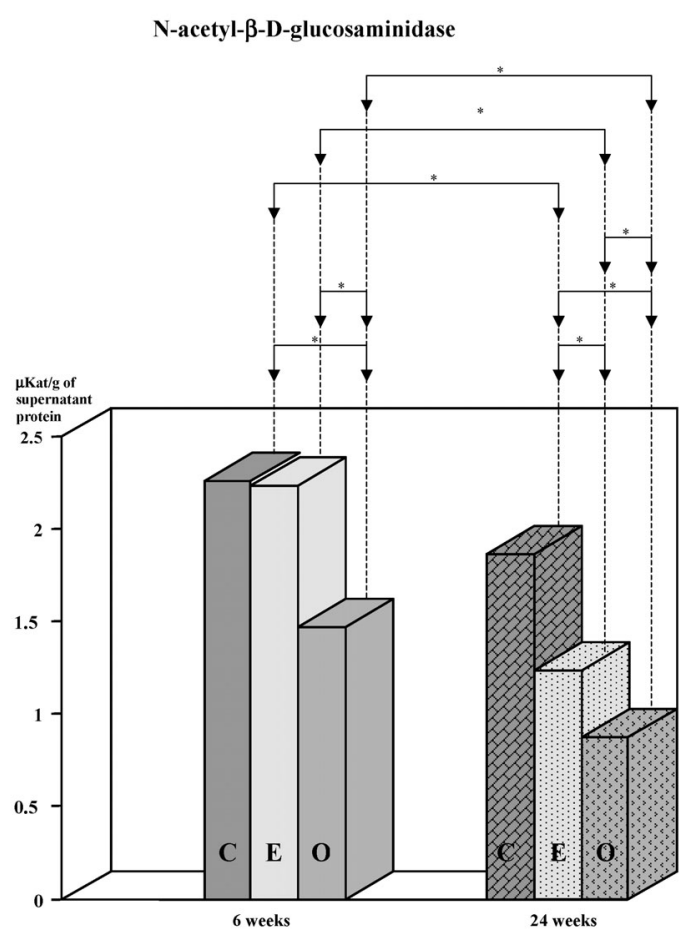

Figure 3. Specific activity of $N$-acetyl- $\beta$-glucosaminidase (HEX) present in supernatant obtained from submandibulary gland homogenates of rats chronically exposed to cadmium.

The activity was determined as described in Materials and Methods. Other details as in Fig. 1.

in rat submandibulary gland, after chronic exposure to $5 \mathrm{mg} / \mathrm{l}$ of $\mathrm{Cd}$ drinking water (related to human "environmental" exposure) and $50 \mathrm{mg} / \mathrm{l}$ (related to human "occupational" exposure). We found accumulation of cad- 
mium in submandibulary glands of rats dependent on the dose and time of "environmental" and "occupational" exposure (Fig. 1). The small increase of $\mathrm{Cd}$ concentration after 24 weeks of "environmental" exposure (in comparison to 6 weeks) suggests, that rat's defense mechanisms are able to protect salivary glands against accumulation of cadmium applied chronically at the "environmental" dose. Our results also might suggest that during "occupational" chronic exposure, the ability of the submandibulary glands similarly as kidneys (Brzóska et al., 2004) to excrete absorbed cadmium was exceeded, and progressive accumulation of cadmium in submandibulary glands occured (Fig. 1). Similar results were also presented when kidneys were used (Brzóska et al., 2003).

The direct treatment of soluble fraction of submandibular glands of control group of rats with even high concentrations of $\mathrm{Cd}$ did not inhibit none of the investigated exoglycosidases (HEX,Man,Gal) ( Fig. 2). Despite of these results we decided to follow the changes in HEX activity in submandibular glands, of rats treated with $\mathrm{Cd}$ for different time and doses (Fig. 3). Our results might suggest that cadmium might damage the biosynthesis of $N$-acetyl- $\beta$-glucosaminidase in submandibulary glands of rats. It is known, that HEX in the submandibulary gland of rats is synthesized by mucous and convoluted tubular cells (Pugh \& Walker, 1961; Hayashi, 1967). We have no data on changes in cell structure of submandibulary gland of rats chronically exposed to cadmium. However, we observed an increase in expression of proliferating cell nuclear antigen (PCNA) and absence of Ki-67 expression in salivary glands of rats exposed to the "environmental" and "occupational" doses of cadmium for 24 weeks. The increase in PCNA and the absence of Ki-67 antigen, suggest the predominance of DNA repair rather than proliferation mechanism (Czykier et al., 2003). In our previous investigation we found damage to epithelial cells of main renal tubules (proximal convoluted tubules and straigh tubules) after "environmental” exposure to cadmium. "Occupational” exposure of rats for 6 weeks blurred the structure of the renal tubular epithelium, caused atrophy of the brush border and partial fragmentation of cells (Brzóska et al., 2003). Cadmium in the submandibulary gland may cause similar disturbances as in kidneys, what may explain the observed decrease of HEX activity in this tissue, as cadmium even at a high concentration has no direct effect on the activity of soluble enzyme preparation (Fig. 2).

Of the three exoglycosidases tested in submandibular glands of rats chronically exposed to cadmium, we found highest changes in HEX activities. $\mathrm{N}$-acetylglucosamine and $\mathrm{N}$-acetylgalactosamine are abundant components of salivary glycoproteins (Wu et al., 1994; Zalewska et al., 1999; 2000). HEX has the highest specific activity among the exoglycosidases of rat submandibulary gland (Fig. 2) (Kamada et al., 1989), similarly as in human gastric mucous membrane (Zwierz et al., 1981). A decrease of the specific activity of HEX during maturation of rats (Fig. 3) is in agreement with report of Przybyło et al. (2004). It has to be checked, if the decrease of HEX activity after chronical exposure of rats to cadmium increases the $N$-acetylhexosamine content in salivary glycoconjugates, both remaining in tissue and excreted in saliva: high (MG1) and low molecular mass (MG2) salivary mucins, lysozyme, lactoferrin, secretory immunoglobulins, acid phosphatase and $\beta$-glucuronidase (Zalewska et al., 1999). The changes in the structure and function of submandibulary gland may explain periodontopathies detected among cadmium smelter workers and the cigarette smokers (Ziętek, 1999).

\section{R E F E R E N C E S}

Brzóska MM, Moniuszko-Jakoniuk J, Kaminski M, Supernak-Bobko D, Zwierz K. (2003) Changes in the structure and function of the kidney in rats chronically exposed to cad- 
mium. Part I. Biochemical and histopathological studies. Arch Toxicol.; 77: 344-52.

Brzóska MM, Stypułkowska A, Zwierz K, Moniuszko-Jakoniuk J. (2004) Urinary activities of $N$-acetyl- $\beta$-D-glucosaminidase and its isoenzyme B in cadmium-exposed rats. Pol $J$ Environm Studies.; 13: 121-5.

Czykier E, Dzięcioł J, Zalewska A, Zwierz K. (2003) Preliminary study of the submandibular gland of rat after long-term cadmium intoxication. Folia Morph.; 62: 305-7.

Douglas PR, Golub EE. (1994) Bacterial-protein interaction in the oral cavity. Adv Dental Res.; 8: 254-62.

Florkin M, Stotz EH, eds (1973) Enzyme Nomenclature. In Comprehensive Biochemistry, vol. 13. Elsevier, Amsterdam, London, New York.

Giles AR. (1987) Guidelines for the use of animals in biomedical research. Thromb Haemost.; 58: 1078-84.

Gornal AG, Bardawill CJ, David MM. (1949) Determination of serum proteins by means of the biuret reaction. $J$ Biol Chem.; 177: 1265-73.

Hayashi M. (1967) Comparative histochemical localization of lysosomal enzymes in rat tissues. J Histochem Cytochem.; 15: 83-92.

Indulski JA. (1996) Kadm. Kryteria zdrowotne środowiska, vol 134 Instytut Medycyny Pracy J. Nofera, Łódź (in Polish).

Kamada A, Kawamura M, Funato N, Nakagawa M, Nagasawa S, Sakaki T. (1989) Changes in rat submandibular gland $N$-acetyl $\beta$ glucosaminidase activity in streptozocin-induced diabetes. $J$ Osaka Dental Univ.; 23: 15-27.

Kano M. (1986) Characterization of hyaluronidase from rat salivary glands. $J$ Osaka Odontol Soc.; 49: 579-91.

Kinoshita M, Kosaka H, Ikeo T, Shioji I, Sakaki T. (1986) Glycosaminoglycan changes in submandibular glands of experimental diabetic rats. $J$ Osaka Dent Univ.; 20: $55-71$.
Lagrelof F, Olivery A. (1994) Caries-protective factors in saliva. Adv Dental Res.; 8: 229-38.

Martinez-Canut P, Lorca A, Magan R. (1995) Smoking and periodontal disease severity. $J$ Clin Periodontol.; 22: 743-9.

Mitsumori K, Shibutani M, Sato S, Onodera H, Nakagawa J, Hayashi Y, Ando M. (1998) Relationship between the development of hepato-renal toxicity and cadmium accumulation in rats given minimum to large amounts of cadmium chloride in the long-term: preliminary study. Arch Toxicol.; 72: 545-52.

Nieuw-Amerongen AN, Odskerk CK, Driessen AA. (1987) Role of mucin from human whole saliva in the protection of tooth enamel against demineralization in vitro. Caries Res.; 21: 297-309.

Przybyło M, Lityńska A, Hoja-Łukowicz D, Kremser E. (2004) Rat submandibular gland during the maturation process: changes in enzyme activities protein and lectin-binding profiles. Physiol Res.; 53: 317-26.

Pugh D, Walker PG. (1961) The localization of $N$-acetyl $\beta$-glucosaminidase in tissues. $J$ Histochem Cytochem.; 9: 242-50.

Shioji I, Asai K, Kim WO, Sanada N, Ikeo T, Sakaki T. (1988) Isolation and properties of rat submandibular gland $N$-acetylhexosaminidase. J Osaka Dental Univ.; 22: 1-16.

Stawinski K, Szponar E, Orkiszewska M. (1987) Występowanie chorób przyzębia i błony śluzowej jamy ustnej u pracowników narażonych na różne czynniki szkodliwe środowiska pracy. Czas Stomat.; 40: 137-41 (in Polish).

Sugiyama K. (1975) A study on $\beta$-glucuronidase isozyme in the salivary glands of rats. $J$ Osaka Odontol Soc.; 39: 623-35.

WHO (1992) Environmental Health Criteria, 134. Cadmium. International Programme on Chemical Safety (IPCS). WHO Geneva.

Wu AM, Csako G, Herp A. (1994) Structure biosynthesis and function of salivary mucins. Mol Cell Biochem.; 137: 39-55. 
Zalewska A, Borzym M, Marcinkiewicz M, Zwierz K. (1999) Glikoproteiny śliny ludzkiej. Mag Stomat.; 10: 28-35 (in Polish).

Zalewska A, Zwierz K, Żółkowski K, Gindzieński A. (2000) Structure and biosynthesis of human salivary mucins. Acta Biochim Polon.; 47: 1067-79.

Zenther A, Heaney TG. (1995) An in vitro investigation on the role of high molecular weight human salivary sulphated glycoprotein in peridontal wound healing. $J$ Peridontol.; 66: $944-55$.
Ziętek M, Baranowski K, Andrzejak R. (1999) Zmiany w przyzębiu u pracowników narażonych na skażenia przemysłowe. Zaawansowanie zmian w zależności od stażu pracy i palenia tytoniu. Czas Stomat.; 52: 451-63 (in Polish).

Zwierz K, Gindzieński A, Głowacka D, Porowski T. (1981) The degradation of glycoconjugates in the human gastric mucous membrane. Acta Med Acad Sci Hung.; 38: 145-52. 